\title{
Note on Recent Developments
}

\section{UN Environment-Advancing the Environmental Rule of Law in the Asia Pacific}

\author{
Andy RAINE \\ Senior Legal Officer and Head of the International Law Unit, \\ UN Environment, Nairobi, Kenya \\ rainea@un.org
}

Emeline PLUCHON

Environmental Law Specialist, Asia and Pacific Office, UN Environment, Bangkok, Thailand

emeline.pluchon@un.org

\section{Introduction}

Effective laws, coupled with empowered institutions and citizens to ensure their implementation, provide the critical enabling environment necessary to deliver the environmental dimensions of the 2030 Agenda for Sustainable Development and other internationally agreed environmental goals.* While most countries have now developed environmental legal frameworks at different levels, effective implementation remains a key challenge for almost all countries. ${ }^{1}$ In addition, many environmental legal frameworks need to be

* The views expressed in this note are those of the authors and do not necessarily represent those of UN Environment.

1 United Nations Environment Programme (UN Environment), Environmental Rule of Law: First Global Report (2019) 3 <https://www.unenvironment.org/resources/assessment/ environmental-rule-law-first-global-report>. 
strengthened to respond to new and emerging issues, including new internationally agreed goals and commitments. The United Nations Environment Programme (UN Environment), working with partners, supports countries around the world to meet these objectives and needs. A central focus of its work is to support countries to advance the environmental rule of law. This report ${ }^{2}$ provides an overview of recent and planned environmental rule of law activities of UN Environment, with a focus on the Asia and Pacific region for the period 2019-2021.

A New Framework for Action by UN Environment to Advance Environmental Rule of Law

The work of UN Environment in the field of environmental law is principally informed by the resolutions of the United Nations Environment Assembly, the UN Environment's Medium-Term Strategy, its Programme of Work, joined with bilateral requests from countries and through regional and sub-regional political forums and the Montevideo Programme on the Development and Periodic Review of Environmental Law (Montevideo Programme). For the period 2019 to 2021, the Environmental Law Branch of the Law Division of UN Environment will strategically focus its work on advancing the environmental rule of law in five core areas in the implementation of these governing instruments: (1) environmental rights; (2) climate change; (3) pollution; (4) environmental crime; and (5) nature. The final scope and nature of these focus areas will be shaped by the priorities and requests of countries identified in each region through the Montevideo Programme for the Development and Periodic Review of Environmental Law.

Support to countries will be delivered under a global UN Environment project entitled 'Addressing Environmental Challenges through the Law' (the Project). The Project will run for three years, concluding in December 2021. It has the core objective of supporting countries to develop enhanced legal frameworks and institutional capacities to deliver on the environmental dimension of the 2030 Agenda for Sustainable Development, as well as Multilateral Environmental Agreements and other regionally or internationally agreed environmental goals. The project has four 'outcome' areas: (a) Countries strengthen international legal frameworks to address priority environmental issues of regional and/or global concern; (b) Countries strengthen their national legal frameworks to address priority environmental issues in an effective and

2 The initial report from UN Environment for this Journal appeared in CJEL 1 (2017) 257-262. 
inclusive manner; (c) National institutions and other relevant legal stakeholders have improved capacities to implement and/or enforce legal frameworks that address priority environmental issues; and (d) Civil society organisations, private sector institutions, media, and the general public have enhanced access to information on legal frameworks, especially rights and obligations, related to the protection of the environment.

Activities for the Asian and Pacific region will be identified and implemented in consultation with national focal points of the Montevideo Programme, and UN country teams. The Montevideo Programme refers to a series of ten-year programmes that guide UN Environment's work related to environmental law. The current fourth programme ends in December 2019, and the next programme will commence in 2020. The United Nations Environment Assembly adopted the fifth Montevideo Programme (Montevideo v) at its fourth meeting, held from 11 to 15 March 2019 in Nairobi. ${ }^{3}$ Previous Montevideo programmes focused on identifying a list of thematic and specific activity areas for UN Environment and the broader environmental law community to implement. Montevideo $\mathrm{v}$ takes a different approach; it is designed as an intergovernmental programme to guide the identification and implementation of priority actions in the field of environmental law for UN Environment, in collaboration with other relevant actors. Its vision is to promote the development and implementation of the environmental rule of law, strengthen the related capacity in countries, and contribute to the environmental dimension of the 2030 Agenda. ${ }^{4}$ The first global meeting of Montevideo national focal points is scheduled for 2020.

A strengthened global network of national focal points for the Montevideo $\mathrm{V}$ programme will also be central to UN Environment's plans to expand its global Environmental Rule of Law assessment report. In January 2019 UN Environment published the first global report on Environmental Rule of Law. ${ }^{5}$ The study focuses on the implementation gap between environmental goals, laws and regulations adopted and the reality on the ground. It highlights global trends as well as opportunities to strengthen the environmental rule of law. UN

3 UN Environment, United Nations Environment Assembly, Fourth Session, 11-15 March 2019, Nairobi, Kenya, UNEP/EA.4/L.24 Fifth Programme for the Development and Periodic Review of Environmental Law (Montevideo v) "Delivering for People and the Planet" UNEP/ EA.4/L.24 <http://web.unep.org/environmentassembly/ministerial-declaration-resolutions -and-decisions-unea-4>.

4 United Nations 2015, Transforming our world: the 2030 Agenda for Sustainable Development, $<$ https://sustainabledevelopment.un.org/post2015/transformingourworld $>$.

5 UN Environment, Environmental Rule of Law: First Global Report <https://www .unenvironment.org/resources/assessment/environmental-rule-law-first-global-report>. 
Environment plans to undertake a regular periodic assessment exercise, allowing stakeholders to see progress and challenges over time regarding the global environmental rule of law. the People

More than 150 national constitutions now recognise or safeguard the right to a healthy environment, including 24 in the Asia Pacific region. ${ }^{6}$ However, a number of countries still do not have any constitutional or legal recognition of this right, including at least 17 in the Asia Pacific region. ${ }^{7}$ The promotion, protection, and respect for environmental rights—including procedural rights such as access to justice, access to environmental information, and participation in environmental decision-making - needs to be strengthened at all levels to ensure effective laws that are adequately implemented, facilitating the environmental rule of law. In addition, even where there is legal recognition of environmental rights, there is too often a lack of access to good information and capacity to understand and operationalise environmental rights.

UN Environment, through the Environmental Rights Initiative, ${ }^{8}$ works with governments and partners such as the Office of the United Nations High Commissioner for Human Rights, to strengthen institutional capacities to develop and implement laws and policies that protect environmental rights. It also supports civil society organisations in their efforts to access information on these rights to give the possibility to every citizen to exercise their rights and to fight for them. In 2018, UN Environment supported a regional workshop on the state of environmental defenders in Asia and the Pacific organised by several civil society organisations. ${ }^{9} \mathrm{~A}$ key outcome was the creation of the first network of environmental defenders in the region; the 'Asia Pacific Network

6 UN Environment, Environmental Rule of Law: First Global Report, (n 5) 159. This number includes countries with a constitutionally protected right to a healthy environment or with constitutional provisions for a healthy environment.

7 Ibid.

8 UN Environment, What is the Environmental Rights Initiative? <https://www .unenvironment.org/explore-topics/environmental-rights-and-governance/what-we -do/advancing-environmental-rights/what-1>.

9 Defending People's Environmental Rights in Asia Pacific: A workshop on the state of environment defenders in the region and exploring collaborations to advance their protection, 24 March 2018, Bangkok, Thailand and 27 March 2018 at the Asia Pacific Peoples' Forum for Sustainable Development 2018, Bangkok, Thailand. 
of Environment Defenders.10 It also supported EarthRights International to establish a regional platform to support environmental defenders across Southeast Asia. Through this regional platform, environmental defenders enhanced their capacity in various fields such as legal strategies, digital and physical security, as well as advocacy. UN Environment also supported the establishment of a clinical environmental law education programme in China and the development of a network of university-based environmental law clinics in the Asia Pacific region. ${ }^{11}$

In 2019, work will continue to advance environmental rights in several key areas. One will be through a partnership with key media agencies and stakeholders to design and implement media outreach and training programs to improve the dissemination of information on environmental rights to the public and give more visibility to attacks on environmental defenders. ${ }^{12}$ Another will be to continue to work with the ASEAN Intergovernmental Commission on Human Rights (AICHR) to promote efforts to explore the possibility of a regional approach or instrument on environmental impact assessment incorporating a rights-based-approach. This initiative follows earlier work with AICH R, as well as support in November 2018 to the China University of Political Science and Law on the Second Forum on Environmental Rule of Law and the Belt and Road Initiative. The forum brought together representatives of various countries, civil society organisations and academia to help strengthen legal frameworks and cooperation in Association of Southeast Asian Nations (ASEAN) countries and China concerning environmental rule of law and investments under the Belt and Road Initiative.

10 Launch statement of the Asia Pacific Network of Environment Defenders (APNED), 4 October 2018 <http://www.chrp.org.uk/2018/launch-statement-of-the-asia-pacific -network-of-environment-defenders-apned/ $>$.

11 UN Environment, 'First environmental law clinic opens in Wuhan University, China'. $<$ https://www.unenvironment.org/zh-hans/node/22786>.

12 See UN Environment, Who are environmental defenders? <https://www.unenvironment .org/explore-topics/environmental-rights-and-governance/what-we-do/advancing -environmental-rights/who>. 


\section{4 \\ Climate Change: Developing and Strengthening National Legal Frameworks}

The effective implementation of the Paris Agreement requires that countries either introduce new laws or revise and strengthen existing ones..$^{13}$ As demonstrated by their Nationally Determined Contributions (NDCs), many countries in Asia and the Pacific have ambitious climate plans to tackle climate change and, according to the Grantham Research Institute on Climate Change and the Environment, there are now over 325 climate change or climate changerelevant laws in the region. ${ }^{14}$ Governments are of course not the only actors that can help in meeting the goals of the Paris Agreement. The private sector, by mobilising finance in sustainable projects such as renewable energy infrastructure, climate-resilient agriculture projects or sustainable transport, also have a critical role to play. However, rules and policies are needed to channel investments in that direction, and governments need to work hand in hand with businesses to achieve this transition.

To support countries to develop and enhance climate change laws, UN Environment has established, in partnership with the United Nations Climate Change Secretariat and the Commonwealth Secretariat, the Law and Climate Change Toolkit. This initiative takes the form of an online and open database that includes legislation related to climate change, and a self-assessment platform that guides countries to identify priority areas to review their climate change law. ${ }^{15}$ In 2018, UN Environment has also pursued some activities that is commenced in 2017, such as the provision of technical and financial support to the Republic of Maldives to develop its climate change legal framework. A draft climate change bill is currently being finalised.

13 Paris Agreement (adopted 12 December 2015, entered into force 4 November 2016), UN Doc. FCCC /CP/2015/10/Add.1.

14 Grantham Research Institute on Climate Change and the Environment, Climate Change Laws of the World and Climate Change Litigation, <http://www.lse.ac.uk/ GranthamInstitute/climate-change-laws-of-the-world/>.

15 UN Environment, United Nations Climate Change Secretariat and Commonwealth Secretariat, The Law and Climate Change Toolkit <https://lcc.eaudeweb.ro/about-us/>. 


\section{$5 \quad$ Combating Marine Litter and Plastic Pollution}

A significant proportion of plastic waste that enters the marine environment comes from several countries in Asia. ${ }^{16}$ Countries are taking action to address the growing problem of marine litter, as evidenced by several regional actions plans such as the Pacific Regional Action Plan on marine litter, ${ }^{17}$ the Coordinating Body on the Seas of East Asia (совSEA)'s Regional Action Plan on Marine Litter, ${ }^{18}$ and national plans such as Indonesia's National Marine Debris Action Plan. ${ }^{19}$ In 2018, China also banned imports of several types of materials, including plastic scrap, forcing countries across the world to change how they manage their plastic waste. ${ }^{20}$ To tackle the issue of marine pollution, laws and regulations are needed to address not only the removal of marine litter, but also focus on the production, use, and disposal of plastic products that will eventually leak into the marine environment.

UN Environment, working with partners, is addressing the issue of marine litter in the region by working on how packaging chains are managed, from design to disposal. In 2018, UN Environment and COBSEA organised a consultation on Packaging Industry Regulations \& Standards for Design, Labelling, Recovery \& Recycling in ASEAN, with the aim of exploring national and regional approaches to developing harmonised packaging standards across ASEAN covering aspects such as plastic labelling or single-use plastic. ${ }^{21}$ Another relevant initiative in 2018 was the publication of a Global Review of National Laws

16 JR JAMBECK, et al, "Plastic waste inputs from land into ocean" Science, vol. 347 No. 6223 (13 February 2015) 768-771; Ocean Conservancy, Stemming the Tide: Land-based strategies for a plastic-free ocean (2015) 3 <https://oceanconservancy.org/wp-content/ uploads/2017/04/full-report-stemming-the.pdf $>$.

17 Secretariat of the Pacific Regional Environment Programme, Pacific Regional Action Plan: Marine Litter 2018-2025 (2018) < https://pipap.sprep.org/content/pacific -regional-action-plan-marine-litter-2018-2025>.

18 Coordinating Body on the Seas of East Asia (COBSEA), RegionalAction Plan on Marine Litter (2008) < https://www.cobsea.org/documents/Meeting_Documents/Marine\%2oLitter/ Marine\%2oLitter\%2oReport\%202008.pdf>.

19 Republic of Indonesia, Indonesia's Plan of Action on Marine Plastic Debris 2017-2025 (2017) $<$ http://www.indonesianwaste.org/en/indonesias-national-plan-of-action-on-marine -plastic-debris-2017-2015-executive-summary-2/>.

20 Chinese Ministry of Environmental Protection, "Announcement of releasing the Catalogues of Imported Wastes Management”, (Announcement no. 39, 2017) <http:// en.pkulaw.cn/display.aspx?cgid $=300517 \&$ lib $=$ law\&EncodingName $=$ big $5>$.

21 UN Environment, совSEA, Regional Solutions to Combat Plastic Pollution: Consultation on Packaging Industry Regulations \& Standards for Design, Labelling, Recovery \& Recycling in ASEAN, 11-12 December 2018, Bangkok, Thailand. 
and Regulations related to plastic bags, disposable single-use plastic items and microbeads. ${ }^{22}$ In 2019, UN Environment will continue its ongoing work in supporting countries in the region to develop national legal frameworks to reduce marine litter and combat plastic pollution. A global guidance tool on this topic is under preparation with the World Resources Institute and will be published later in 2019.

Strengthening Laws and Enforcement to Combat Illegal Trafficking in Wildlife and Wildlife Crime

Illegal trade of wildlife and wildlife crime are considered as one of the biggest threats to biodiversity, amongst other material impacts. A number of countries in Asia are increasingly becoming major consumer markets of illegally traded environmental products. ${ }^{23}$ Rhino horn, elephant ivory and tiger parts are among the most popular products being trafficked from various parts of Southeast Asia, as well as from Africa into Asia. ${ }^{24}$ The lack of data related to wildlife crime, the weak implementation of relevant legal instruments such as the Convention on International Trade in Endangered Species of Wild Fauna and Flora (CITES), ${ }^{25}$ the limited use of existing criminal legislation including non-environmental laws, as well as the lack of enforcement and cooperation at the national and regional level are among the challenges in the fight against illegal trafficking of wildlife.

In response, UN Environment is supporting countries to develop and strengthen their legal frameworks. One such initiative is through technical and financial support to the Solomon Islands. With UN Environment's assistance, the Solomon Islands has developed regulations under the Wildlife Protection and Management Act of 2017, enhancing the country's implementation of the CiTEs. Another relevant initiative in 2018, was a partnership

22 UN Environment, Legal Limits on Single-Use Plastics and Microplastics: A Global Review of National Laws and Regulations (2018) <https://www.unenvironment.org/resources/ publication/legal-limits-single-use-plastics-and-microplastics-global-review-national>.

23 UN Environment, The State of Knowledge of Crimes that have Serious Impact on the Environment (2018) 2. https://www.unenvironment.org/resources/publication/state -knowledge-crimes-have-serious-impacts-environment.

24 United Nations Office on Drugs and Crime, Environmental Crime-The Trafficking of Wildlife and Timber (2012) $1<\mathrm{https}$ ://www.unodc.org/res/cld/bibliography/environmental -crime-the-trafficking-of-wildlife-and-timber_html/TOC12_fs_environment_EN_HIRES .pdf>.

CITES 993 UNTS 243 . 
with the International Union for Conservation of Nature (IUCN) Academy of Environmental Law to increase access to Asia and Pacific legislation implementing the CITES through the United Nations Information Portal on Multilateral Environmental Agreements (InforMEA). Together with partners, UN Environment also hosted the 2018 Asia Environmental Enforcement Awards in Bangkok to recognise and celebrate excellence in enforcement by government officials and institutions combating transboundary environmental crime, including wildlife crime. UN Environment and partners are preparing the next awards ceremony for 2019 .

Judiciaries play a crucial role in the implementation of environmental laws. UN Environment, working with key partners such as the Asian Development Bank, is supporting judiciaries across Asia and the Pacific to strengthen their capacity to decide cases on the environment. In February 2018, UN Environment and the Lahore High Court, in partnership with the Punjab Judicial Academy, the Asian Development Bank, the Raoul Wallenberg Institute, the IUCN World Commission on Environmental Law, the Global Judicial Institute on the Environment, the UN Special Rapporteur on Human Rights and the Environment, and Widener University Delaware Law School, organised the 'Asia Pacific Judicial Colloquium on Climate Change: Using Constitutions to Advance Environmental Rights and Achieve Climate Justice', in Lahore, Pakistan. Over 250 judges, lawyers and experts in environmental law from the region and globally met to discuss and advance the role of judiciaries in advancing environmental rights and climate justice. ${ }^{26}$

In July 2018, UN Environment supported an unprecedented judicial summit in Beijing. The training, organised by the Supreme People's Court, the Supreme People's Procuratorate and ClientEarth, assembled over 300 judges and 150 prosecutors from across China. One of the main outcomes was the adoption of the Beijing Declaration. The declaration affirms the important role of the judiciary in global environmental governance and calls for increased judicial cooperation in the application of the environmental rule of law, including through information-sharing and coordination among judicial systems worldwide.

26 UN Environment, 'Asia and the Pacific judicial colloquium on climate justice' <https:// www.unenvironment.org/pt-br/node/22782>. 
Later in the year, in October 2018, 180 judges from 14 countries assembled in Nay Pyi Taw, in Myanmar, to discuss environmental and climate change issues at the Asia Pacific Judicial Conference on Environmental and Climate Change Adjudication hosted by the Supreme Court of the Union of Myanmar, the Asian Development Bank and UN Environment. ${ }^{27}$ In 2019, UN Environment together with the Asian Development Bank are exploring the possibility to build a judicial training programme for Pacific countries on environmental and climate change law and adjudication.

27 UN Environment, Asia-Pacific Judicial Conference on Environmental and Climate Change Adjudication, 29-30 October 2018, Nay Pyi Taw, Myanmar <https://www .unenvironment.org/events/conference/asia-pacific-judicial-conference-environmental -and-climate-change-adjudication>. 